\title{
Maksimalisasi Pemecahan Masalah dan Pemanfaatan Teknologi Penunjang Pendidikan Bahasa Indonesia (Mengenal Teks Deskriptif)
}

\author{
Hanna Kartika Sari \\ Email : hanna.kartika2453@student.unri.ac.id \\ Program Studi Pendidikan Bahasa dan Sastra Indonesia, Universitas Riau
}

\section{Pengantar}

Berbahasa merupakan kegiatan yang selalu mengisi berbagai bidang kehidupan umat, misalnya, bidang ekonomi, hukum, politik, dan pendidikan. Kegiatan tersebut berlangsung, baik secara transaksional maupun interaksional. Melalui kegiatan tersebut pemakai bahasa berusaha memerikan, memaparkan, memberikan alasan, menceritakan, atau menyarankan sesuatu. Bahkan, van Ek dan Alexander (dalam Brown,1994:234) mendaftar 70 fungsi bahasa. Pembelajaran menulis dalam kebahasaan terbagi menjadi menulis argumentasi, narasi, deskripsi, eksposisi, persuasi, dan laporan. Pada penelitian ini penulis membahas menulis teks deskripsi. teks deskripsi adalah melukiskan atau menggambarkan suatu objek atau peristiwa yang dialami oleh penulis sehingga pembaca dapat merasakan apa yang dideskripsikan oleh penulis melalui tulisan. Pembelajaran menulis memerlukan pengetahuan yang luas dan pola pikir yang logis. Pengetahuan yang luas tidak terlepas dari kegiatan membaca, maka kegiatan menulis harus diimbangi dengan kegiatan membaca. Kegiatan tersebut menjadi kendala dan hambatan bagi siswa untuk melaksanakan tulis-menulis secara maksimal. Bahasa yang digunakan dalam tulisan harus jelas, mudah dipahami, dan menggunakan kalimat yang teratur. Penggunaan bahasa yang jelas dan teratur akan menentukan keberhasilan dalam membuat teks. Jenis kalimat yang digunakan dalam teks pun beragam jenisnya. Pembelajaran pokok menulis bahasa dalam teks pada dasarnya dibagi menjadi dua pokok bahasa, yaitu menulis teks rekaan (fiksi) dan menulis teks bukan rekaan. Teks rekaan terdiri dari narasi, cerpen, novel, dan drama. Sedangkan menulis bukan rekaan terdiri, menulis teks deskripsi, argumentasi, eksposisi, persuasi, dan laporan. Teks rekaan berbeda dengan teks bukan rekaan. teks bukan rekaan isinya lebih bersifat memberi penjelasan. Pokok pikiran yang dapat memperluas pengetahuan pembaca teks. Sedangkan dalam teks rekaan bersifat khayalan (imajinasi) walaupun disertai pula 
dengan pemaparan. Dalam dunia pendidikan, khususnya pendidikan bahasa, penggunaan bahasa dikemas dalam empat aspek keterampilan berbahasa (menyimak, membaca, berbicara, dan menulis). Keempat aspek keterampilan berbahasa tersebut menjadi landasan pembelajaran sejak SD hingga perguruan tinggi. Setiap pebelajar diberdayakan kompetensinya untuk menguasai keempat aspek tersebut (meskipun sulit mencari orang yang menguasai keempatnya). Keterampilan berbahasa merupakan aspek kemampuan berbahasa yang menjadi sasaran tumpu para pembelajar bahasa. Oleh sebab itu, dalam dunia pendidikan para pengajar terus berupaya meningkatkan keberhasilan dalam pembelajaran bahasa melalui pencapaian kompetensi berbahasa, yakni menyimak, membaca, berbicara, dan menulis. Bahkan, dalam KTSP untuk SMA (MA) dinyatakan bahwa standar kompetensi lulusan untuk pelajaran Bahasa Indonesia adalah sebagai berikut:

1. Mendengarkan Memahami wacana lisan dalam kegiatan penyampaian berita, laporan, saran, berberita, pidato, wawancara, diskusi, seminar, dan pembacaan karya sastra berbentuk puisi, cerita rakyat, drama, cerpen, dan novel.

2. Berbicara Menggunakan wacana lisan untuk mengungkapkan pikiran, perasaan, dan informasi dalam kegiatan berkenalan, diskusi, bercerita, presentasi hasil penelitian, serta mengomentari pembacaan puisi dan pementasan drama.

3. Membaca Menggunakan berbagai jenis membaca untuk memahami wacana tulis teks nonsastra berbentuk grafik, tabel, artikel, tajuk rencana, teks pidato, serta teks sastra berbentuk puisi, hikayat, novel, biografi, puisi kontemporer, karya sastra berbagai angkatan dan sastra Melayu klasik

4. Menulis Menggunakan berbagai jenis wacana tulis untuk mengungkapkan pikiran, perasaan, dan informasi dalam bentuk teks narasi, deskripsi, eksposisi, argumentasi, teks pidato, proposal, surat dinas, surat dagang, rangkuman, ringkasan, notulen, laporan, resensi, karya ilmiah, dan berbagai karya sastra berbentuk puisi, cerpen, drama, kritik, dan esei.

Setiap pembelajaran memerlukan berbagai komponen karena pembelajaran merupakan sebuah sistem. Keberhasilan pembelajaran merupakan kondisi kumulatif dari semua komponen yang terlibat. Dengan kata lain, 
keberhasilan suatu pembelajaran bukan disebabkan oleh satu komponen, melainkan banyak komponen yang turut andil. Begitupun sebaliknya. Kegagalan suatu pembelajaran dapat disebabkan oleh banyak komponen. Perangkat pembelajaran yang turut andil dalam keberhasilan pembelajaran adalah kurikulum, guru, metode, bahan, media, dan alat penilaian di samping siswa dan kondisi kelas.

Pembelajaran bahasa Indonesia bagi siswa berkedudukan sangat penting dalam sistem pendidikan nasional di Indonesia disebabkan oleh peran bahasa Indonesia yang sangat strategis sebagai bahasa pengantar pendidikan dan bahasa nasional (Politik Bahasa Nasional, 1976:22). Dengan Kurikulum 2013 (K-13), paradigma pengajaran bahasa Indonesia yang berpusat pada guru dan isi materi ajar yang mengutamakan capaian hasil belajar kemampuan kognitif sudah berubah menjadi paradigma pembelajaran bahasa yang mengutamakan proses dan kebermaknaan hasil belajar. Jargon pembelajaran bahasa yang berlaku sekarang yaitu, "Jangan ajari siswa semata-mata pengetahuan bahasa tetapi belajarkan mereka berbahasa sesuai kebutuhan komunikasi dalam dunia mereka". Dunia pendidikan siswa menuntut kemampuan berbahasa Indonesia yang cermat menaati kaidah kebahasaan dan elok berkesantunan tutur sesuai dengan konteks komunikasi. Pembelajaran bahasa yang menyeluruh dipandang sebagai proses pembentukan karakter kepribadian yang tercermin dari aspek pengetahuan, sikap, dan keterampilan. Pembelajaran bahasa Indonesia yang dilaksanakan dengan inovasi dan kreasi yang menyenangkan dapat memberi siswa kemampuan berbahasa Indonesia yang benar sesuai kaidah bahasa dan baik menurut etika komunikasinya.

Selain itu, kemampuan siswa dalam berbahasa Indonesia dapat memberi manfaat akademis bagi pembelajaran bidang studi lain. Pembelajaran bahasa Indonesia yang efektif dan efisien dapat berdampak positif bagi siswa, yaitu menjadikan siswa mahir berbahasa Indonesia, baik dalam percakapan sehari-hari maupun dalam pemerolehan informasi ilmu pengetahuan dan teknologi. Siswa yang mahir berbahasa Indonesia cenderung akan lebih mudah dan lebih cepat dalam proses belajar dalam berbagai bidang sehingga berpeluang untuk berprestasi dan berdaya saing tinggi dalam dunia pendidikan dan dunia kerja. 


\section{Tindakan yang Dilakukan}

\section{a. Mengenal Teks Deskriptif beserta karakteristik dan unsur pembentuknya}

Ahli bahasa Gorys Keraf, menjabarkan teks deskripsi sebagai salah satu bentuk wacana, yang secara khusus berusaha menyajikan suatu objek yang dibahas, secara gamblang sehingga membuat objek tersebut seolah-olah bisa dilihat langsung oleh pembaca. Atau dengan kata lain, seakan-akan objek yang dibahas benar-benar berada di depan mata pembaca. Pemakaian kalimat dalam teks deskripsi sudah dikemas dalam bentuk yang menarik dan memiliki karakter sehingga pembaca tidak akan merasa jenuh ketika membaca teks deskripsi. Selain pada bentuk kalimat dan kebahasaan yang menarik, di dalam teks ini pembaca pun harus merasakan apa yang telah dideskripsikan penulis melalui tulisan. Menulis teks deskripsi yang digambarkan pun bisa berupa peristiwa yang dialami penulis atau menggambarkan suatu objek dalam bentuk teks, dan pembaca dapat merasakan apa yang digambarkan dalam teks deskripsi. Kegiatan menulis teks deskripsi, siswa dituntut mampu menyusun kalimat. Kalimat yang baik untuk menyampaikan gagasanya sehingga menghasilkan sebuah teks deskripsi yang padu. Teks yang padu terdiri dari paragraf-paragraf yang di dalamnya mengandung kalimat-kalimat. Agar gagasan tersebut dapat dipahami maka kalimat yang dibuat harus jelas. Oleh karena itu dalam membuat teks harus memperhatikan unsur kalimat dan kata hubung, agar kalimat yang dibuat teratur dan mudah dipahami. Bahasa Indonesia memiliki banyak jenis kalimat yang harus diketahui peserta didik, dengan mengenal beberapa ciri kalimat berdasarkan fungsi serta cara pengucapan atau penulisannya. Salah satu jenis kalimat yang harus siswa ketahui ketika belajar bahasa Indonesia kalimat majemuk bertingkat. Dalam sebuah tulisan tentu siswa lebih memperhatikan penggunaan kalimat yang tepat. Dalam penelitian ini, penulis lebih memfokuskan pada kalimat majemuk bertingkat, hal ini dikarenakan siswa terkadang belum bisa 
mengidentifikasi klausa yang terdapat dalam suatu kalimat. Keahlian ini sangat penting bagi siswa jika ingin menciptakan kalimat yang efektif dalam teks serta menyunting suatu kalimat hingga teks agar, suatu kalimat menjadi kalimat yang ideal dalam penulisan dengan baik dan tepat kepada para pembaca dan pendengar. Dengan belajar kalimat majemuk, siswa dapat menggunakan kalimat dalam bentuk yang sederhana, tanpa kehilangan inti, dan dapat dipahami oleh semua orang.

\section{b. Kesiapan pengajar dan siswa}

Perekayasaan proses pembelajaran dapat didesain oleh guru sedemikian rupa. Idealnya pendekatan pembelajaran untuk siswa pandai harus berbeda dengan kegiatan siswa berkemampuan sedang atau kurang walaupun untuk memahami konsep yang sama karena setiap siswa mempunyai keunikan masing-masing. Hal ini menunjukkan bahwa pemahaman guru terhadap pendekatan, model, strategi, metode dan teknik pembelajaran tidak bisa diabaikan. Komponen membuka pelajaran menurut Uzer Usman adalah sebagai berikut :

1) Menarik perhatian siswa dengan gaya mengajar, penggunaan media pembelajaran dan pola interaksi pembelajaran yang bervariasi.

2) Menimbulkan motivasi, disertasi kehangatan dan keantusiasan, menimbulkan rasa ingin tahu, mengemukakan ide yang bertentangan, dan memperhatikan minat atau interes siswa.

3) Memberi acuan melalui berbagai usaha seperti mengemukakan tujuan pembelajaran dan batas-batas tugas, menyarankan langkah-langkah yang akan dilakukan, mengingatkan masalah pokok yang akan dibahas, dan mengajukan beberapa pertanyaan.

4) Memberikan apersepsi (memberikan kaitan antara materi sebelumnya dengan materi yang akan dipelajari) sehingga materi yang dipelajari merupakan suatu kesatuan yang utuh yang tidak terpisah-pisah.

\section{c. Melakukan penelitian terhadap suatu objek sekitar yang nantinya} menjadi bahan dalam pembuatan teks deskriptif

Dalam rangka meningkatkan kualitas pembelajaran melalui berbagai inovasi pembelajaran tersebut di atas, sampailah kita pada solusi yang perlu kita lakukan. Dalam menawarkan empat inovasi pembelajaran, yakni model sinektik, image streaming, jigsaw, dan intai gagasan. Keempat model pembelajaran tersebut diharapkan dapat membangkitkan semangat guru dalam membelajarkan siswa dan mampu meningkatkan kompetensi siswa. Model sinektik dikembangkan oleh William J.J. Gordon (Joyce dan Weil, 
1986:161). Model ini dikembangkan dalam rangka meningkatkan berpikir kreatif melalui pemecahan masalah. Model ini dikembangkan dengan prosedur fokus, pengandaian, gagasan, dan penuangan gagasan. Melalui model ini siswa dilatih untuk berpikir kreatif dalam pemecahan masalah. Model Jigsaw dikembangkan untuk meningkatkan kemampuan berbicara siswa. Prosedur pelaksanaannya siswa dikelompokkan menjadi kelompok kecil (2-4 orang) sebagai home group dan expert group. Untuk melaksanakannya ada enam tahap yang dilalui. Keenam tahap tersebut adalah sebagai berikut.

Tahap 1: Dalam setiap home group diberi bacaan atau tugas yang berbeda.

Tahap 2: Anggota kelompok pergi bergabung dengan anggota kelompok lain membentuk experts group untuk memecahkan masalah yang sama.

Tahap 3: Experts group membubarkan diri setelah mendapat jawaban.

Tahap 4: Siswa bergabung kembali di home group untuk saling menukarkan jawaban dengan menjelaskan/mengomunikasikan semua temuannya pada experts group. Tahap

5: Evaluasi terhadap materi yang diperolehnya secara individu.

Tahap 6: Penghargaan kelompok. Model Image Streaming dikembangkan oleh Wenger (2004). Image streaming merupakan sebuah metode untuk mengalirkan bayangan. Wenger (2004) mencoba menawarkan metode ini sebagai inovasi dari metode Sokrates dan Einstein. Prinsip kunci metode sokrates adalah mendeskripsikan persepsi-persepsi mengenai berbagai hal kepada pendengar atau alat perekam agar dapat mempersepsi lebih banyak.

Metode Einstein menekankan dasar-dasar pemikiran visual. Menurut Einstein penglihatan berisi lebih banyak informasi detail daripada indera lainnya. Menurut studi EEG (Electroencephalographic), delapan puluh persen dari area otak manusia terlibat dalam respon visual. Untuk melakukan Image streaming kita perlu memerhatikan hal-hal sebagai berikut:

(1) biarkan yang lebih halus dan dalam memperlihatkan kepada Anda. Jangan langsung memutuskan dengan sadar apa yang ingin Anda lihat dan kemudian Anda gambarkan. Hubungkan dengan bayangan-bayangan yang benar-benar hadir di hadapan Anda sekarang juga, apa pun bayangan-bayangan itu,

(2) tutup mata untuk melihat dengan lebih bebas,

(3) apa pun kesan yang Anda temukan, betapapun remeh, sederhana, tak berhubungan: bahkan warna atau garis yang tampaknya tak berarti. 
(4) Deskripsikan bayangan itu dengan lantang kepada fokus eksternal (selain atau di luar diri Anda). Pendengar langsung adalah yang terbaik; alat perekam juga baik. Tidak boleh kurang dari itu,

(5) deskripsikan dengan cepat dan mengalir dengan detail inderawi yang kaya, berkesinambungan, sekalipun hanya sekadar sekilas dan ringkas. Hal ini memaksa lebih banyak bayangan bebas hadir dan bermunculan,

(6) tanpa menghiraukan taktik yang Anda gunakan untuk mendapatkan beberapa jenis kesan dan suatu aliran deskripsi yang terjadi: perhatikan kapan pemandangan berubah dan bayangan-bayangan lain hadir dan muncul, dan deskripsikan semua, dan

(7) biarkan diri Anda dikejutkan oleh ungkapan bayangan Anda kepada Anda. Model intai gagasan dikembangkan oleh penulis untuk mengembangkan daya kritis dalam pembelajaran membaca. Sebelum membaca teks, siswa dibangkitkan pikirannya untuk menerka gagasan yang ada di dalam teks. Pada saat membaca teks pikiran siswa mencocokkan gagasan yang ada pada teks dan yang diterkanya. Setelah selesai membaca, siswa diminta untuk memeriksa (membandingkan) antara gagasan yang diterka dengan gagasan yang ada pada teks.

\section{Sarana Pendukung}

Menurut Kamus Besar Bahasa Indonesia KBBI menyatakan bahwa sarana adalah segala sesuatu yang dapat dipakai sebagai alat dalam mencapai maksud atau tujuan. Dan prasarana adalah segala sesuatu yang merupakan penunjang utama terselenggaranya suatu proses (usaha, pembangunan, proyek). Menurut Moenir (1992-119), mengatakan sarana adalah segala jenis peralatan, perlengkapan kerja dan fasilitas yang berfungsi sebagai alat utama atau pembantu dalam pelaksanaan pekerjaan, dan juga dalam rangka kepentingan yang sedang berhubungan dengan organisasi kerja. Dari pengertian sarana yg di katakan Moenir tersebut jelas memberi petunjuk sarana merupakan seperangkat alat yang digunakan dalam suatu proses kegiatan baik alat tersebut. Sementara prasarana adalah peralatan pembantu atau juga peralatan utama, dan kedua alat tersebut berfungsi untuk mewujudkan suatu tujuan yang ingin dicapai. Maka dapat dijabarkan sebagai berikut:

\section{a. Google classroom}

Google Classroom adalah layanan gratis yang dikembangkan Google untuk sekolah yang ditujukan untuk menyederhanakan mendistribusikan, dan menilai tugas dengan cara tanpa kertas. Tujuan utamanya adalah merampingkan 
berbagi file antara siswa dan guru. Dengan menggunakan google classroom guru bisa membuat kelas maya, mengajak siswa gabung dalam kelas, memberikan informasi terkait proses KBM, memberikan materi ajar yang bisa dipelajari siswa baik berupa file paparan maupun video pembelajaran, memberikan tugas kepada siswa, membuat jadwal pengumpulan tugas dan lain.

\section{b. WA}

WhatsApp adalah aplikasi pesan instan untuk smartphone, jika dilihat dari fungsinya WhatsApp hampir sama dengan aplikasi SMS yang biasa Anda pergunakan di ponsel lama. Tetapi WhatsApp tidak menggunakan pulsa, melainkan data internet. Jadi, di aplikasi ini sobat tak perlu khawatir soal panjang pendeknya karakter. Tidak ada batasan, selama data internet sobat memadai. Meskipun merupakan aplikasi pesan instan, ada yang unik dari WhatsApp. Jadi, sistem pengenalan kontak, verifikasi dan pengiriman pesan tetap dilakukan melalui nomor ponsel yang sudah terlebih dahulu didaftarkan. Sebagai aplikasi pesan instan, WhatsApp memiliki peranan penting dalam berkomunikasi, baik untuk personal ataupun grup. Dengan WhatsApp, pengguna dapat berkirim pesan teks, foto, audio, video, dokumen, serta melakukan panggilan audio dan video.

\section{c. Google meet/zoom}

Google Meet (sebelumnya dikenal Hangouts Meet) adalah layanan komunikasi video yang dikembangkan oleh Google. Aplikasi ini merupakan salah satu dari dua Aplikasi yang nantinya akan mengganti Google Hangouts, yang lainnya adalah Google Chat. Apabila kegiatan meeting sudah selesai, atau kita hendak keluar dari kegiatan meeting, cukup klik tombol "tutup" pada bagian tengah layar, atau klik tombol "back" pada menu navigasi di bagian bawah layar smartphone android.

Zoom merupakan aplikasi yang menyediakan layanan konferensi jarak jauh dengan menggabungkan konferensi video, pertemuan online, obrolan, hingga kolaborasi seluler. Aplikasi ini banyak digunakan sebagai media komunikasi jarak jauh.

\section{d. Kuota Internet}

Paket data internet atau sering disebut dengan kuota internet menjadi sarana yang sangat mendukung demi tercapainya pembelajaran ini. Sebab, jika tidak ada kuota internet maka aktivitas pembelajaran menulis teks deskripsi tidak dapat berjalan, sebagian besar siswa tentunya menggunakan kuota internet demi menjalankan aplikasi yang ada di dalam handphone-nya tidak terkecuali media sosial instagram. Dengan adanya kuota internet ini guru dan para siswa dapat melaksanakan kegiatan pembelajaran tersebut tentu sebelumnya masing-masing siswa memiliki gawai dan berada dalam kondisi jaringan internet yang stabil. 


\section{e. Jaringan Internet}

Internet adalah salah satu sarana yang sangat dibutuhkan dalam kehidupan sehari-hari. Bagaimana tidak? Internet menjadi wadah dalam mencari sebuah informasi atau menemukan berbagai hal yang ada di dalam perangkat lunak yang tersambung dengan koneksi internet. Khozaimi (2017) internet adalah sebuah sarana yang menjadi salah satu kebutuhan oleh para peserta didik saat ini, internet dapat membantu memperoleh informasi serta berbagai referensi. Jaringan internet menjadi pelengkap dalam berbagai sektor dan tidak terlepas dari berbagai aktivitas, terlebih pada saat ini yang dapat dijumpai hampir semua aplikasi, baik itu desktop, website, mobile, yang difungsikan dalam lapisan bidang, baik bidang pendidikan, bank, logistik, transportasi dan lain-lain (Rahman et al., 2020). Dalam (Pusat Bahasa Kemdikbud, 2016) internet adalah jaringan komunikasi elektronik yang mampu menghubungkan dan memberi fasilitas terhadap komputer agar terorganisasi melalui satelit atau telepon di seluruh dunia.

Dari beberapa pengertian di atas, maka sarana ini menjadi hal yang sangat mendukung adanya pembelajaran daring pada materi teks laporan hasil observasi menggunakan. Dengan ini sebuah aplikasi akan berjalan apabila memiliki koneksi atau jaringan yang cepat dan stabil. Sehingga, aktivitas pembelajaran itu dapat tercapai dengan baik.

\section{f. Telegram}

Merupakan fitur yang memudahkan untuk mengirim dan menerima pesan, mengirim gambar, pesan suara, file dan melakukan panggilan video.

\section{g. Youtube}

Merupakan perkumpulan video yang diupload dari berbagai sumber, youtube memungkinkan untuk mencari video tontonan edukasi yg membantu proses belajar mengajar dan hiburan

\section{h. Latop/Hp}

Media digital pntar yang memungkinkan untuk mengakses dan membuat berbagai tugas dan sumber informasi belajar dan mengajar selama daring

\section{Tindakan Solutif}

Seorang guru merupakan sosok pengajar sekaligus dalah pemberi arahan dan solusi bagi siwa saat proses belajar mengajar, setiap permasalahan dan kesulitan yang di alami siswa saat belajar makan pengajar menyediakan tindakan solutif, adapun tindakan solutif tersebut antara lain:

a. Jika ada beberapa siswa yang tidak atau belum memiliki alat piranti digital seperti handphone maka setiap siswa dapat meminjam atau membeli perangkat tersebut. Jika masih tidak memungkinkan, siswa dapat menggunakan handphone orang tua masing-masing atau bisa juga berkunjung ke rumah teman sejawat untuk belajar bersama serta meminta tolong 
(meminjam akun instagram) agar dapat menulis teks deskripsi yang nantinya diunggah ke media sosial instagram, namun tetap mencantumkan nama pemilik atau pembuat teks deskripsi, hal ini tentunya sudah diketahui oleh guru. Solusi yang dapat dilakukan oleh guru salah satunya adalah dengan membagi siswa dalam beberapa kelompok (Khasanah, 2018). Dengan hal ini dapat meminimalisir bagi siswa yang belum atau tidak memiliki handphone.

b. Jika ada sebagian siswa yang memiliki kendala dalam hal jaringan, sehingga tidak dapat memposting gambar serta caption teks deskripsi ke media sosial instagram. Maka tindakan solutif yang dapat dilakukan adalah siswa dapat mencari atau mengusahakan di mana sumber atau tempat adanya jaringan yang stabil.

c. Jika tidak adanya atau kurangnya kuota internet atau paket data maka siswa dapat membeli paket data internet atau meminta bantuan hostpot perangkat lain yang terhubung ke jaringan internet hal ini bisa teman, guru ataupun orang tua. Solusi lainnya adalah dengan mencari atau menggunakan Wi-Fi sekitar apabila jaringan tersebut terkoneksi dengan baik.

d. Jika aplikasi belum atau tidak terinstal/terunduh serta terkendala dalam mengoperasikannya maka solusinya guru memberikan arahan atau bimbingan untuk menginstal aplikasi tersebut di App Market atau Play Store di handphone masing-masing sesuai dengan keperluan dan dapat mempelajari cara menggunakannya atau mengoperasikannya dari berbagai macam sumber. Misalnya mencari di google, tutorial YouTube, melalui guru, orang tua, atau teman sejawat yang sudah mahir menggunakan dan atau mengoperasikan media sosial instagram tersebut.

\section{Simpulan}

Dapat disimpulkan bahwa setiap pembelajaran memerlukan berbagai komponen karena pembelajaran merupakan sebuah sistem. Keberhasilan pembelajaran merupakan kondisi kumulatif dari semua komponen yang terlibat. Dengan kata lain, keberhasilan suatu pembelajaran bukan disebabkan oleh satu komponen, melainkan banyak komponen yang turut andil. Begitupun sebaliknya. Kegagalan suatu pembelajaran dapat disebabkan oleh banyak komponen. Perangkat pembelajaran yang turut andil dalam keberhasilan pembelajaran adalah kurikulum, guru, metode, bahan, media, dan alat penilaian di samping siswa dan kondisi kelas.

Pembelajaran bahasa Indonesia bagi siswa berkedudukan sangat penting dalam sistem pendidikan nasional di Indonesia disebabkan oleh peran bahasa 
Indonesia yang sangat strategis sebagai bahasa pengantar pendidikan dan bahasa nasional (Politik Bahasa Nasional, 1976:22). Dengan Kurikulum 2013 (K-13), paradigma pengajaran bahasa Indonesia yang berpusat pada guru dan isi materi ajar yang mengutamakan capaian hasil belajar kemampuan kognitif sudah berubah menjadi paradigma pembelajaran bahasa yang mengutamakan proses dan kebermaknaan hasil belajar. Jargon pembelajaran bahasa yang berlaku sekarang yaitu, "Jangan ajari siswa semata-mata pengetahuan bahasa tetapi belajarkan mereka berbahasa sesuai kebutuhan komunikasi dalam dunia mereka". Dunia pendidikan siswa menuntut kemampuan berbahasa Indonesia yang cermat menaati kaidah kebahasaan dan elok berkesantunan tutur sesuai dengan konteks komunikasi. Pembelajaran bahasa yang menyeluruh dipandang sebagai proses pembentukan karakter kepribadian yang tercermin dari aspek pengetahuan, sikap, dan keterampilan. Pembelajaran bahasa Indonesia yang dilaksanakan dengan inovasi dan kreasi yang menyenangkan dapat memberi siswa kemampuan berbahasa Indonesia yang benar sesuai kaidah bahasa dan baik menurut etika komunikasinya.

Selain itu, kemampuan siswa dalam berbahasa Indonesia dapat memberi manfaat akademis bagi pembelajaran bidang studi lain. Pembelajaran bahasa Indonesia yang efektif dan efisien dapat berdampak positif bagi siswa, yaitu menjadikan siswa mahir berbahasa Indonesia, baik dalam percakapan sehari-hari maupun dalam pemerolehan informasi ilmu pengetahuan dan teknologi. Siswa yang mahir berbahasa Indonesia cenderung akan lebih mudah dan lebih cepat dalam proses belajar dalam berbagai bidang sehingga berpeluang untuk berprestasi dan berdaya saing tinggi dalam dunia pendidikan dan dunia kerja.

\section{Referensi}

Arikunto, Suharsimi. 2012. Dasar-dasar Evaluasi Pendidikan: Edisi Kedua. Jakarta : Bumi Aksara Basrowi, \& Suwandi. 2008. Memahami Penelitian Kualitatif. Jakarta :

Rineka Cipta Chaer, Abdul. 2015. Sintaksis Bahasa Indonesia. Jakarta : Rineka Cipta Dalman. 2018. Keterampilan Menulis. Depok :Raja Grafindo Persada Finoza,

Lamuddin. 2018. Komposisi Bahasa Indonesia. Jakarta : Diksi Kosasih. 2019. Jenis-jenis Teks. Bandung. 
Yrama Widya Kurniasari, Nurlaila Anna. 2015. Pedoman Umum Ejaan Bahasa Indonesia. Yogyakarta : Pustaka Baru Press Moleong, L.J. 2013. Metode Penelitian Kualitatif. Bandung

Remaja Mulyati. 2019. Terampil Berbahasa Indonesia. Jakarta : Prenadamedia Group Ramlan. 2005. Ilmu Bahasa Indonesia Sintaksis. Yogyakarta : C.V. Karyono Ratna,

Reni 2010. Analisis Kalimata Tunggal Berdasarkan Fungsi Sintaksis pada Karangan Deskripsi Siswa Kelas XI SMA Darul Ma'Arif Jakarta Selatan. Jakarta. Universitas

Muhammadiyah Prof. Hamka. Samosir, \& Haryanti. 2016. Menulis. Tangerang : PT Pustaka Mandiri Suhardi. 2013. Dasar-dasar Ilmu Sintaksis Bahasa Indonesia

Jurnal online Djafar, Hamsiah. 2017. "Penggunaan Kalimat Majemuk dalam Karya Tulis Mahasiswa Fakultas Trabiyah dan Keguruan UIN Alauddin Makasar.

Edisi

IX.

http://www.google.com/url?sa=t\&source=web\&rct=j\&url=http://jo

urnal.uinalauddin.ac.id/index.php/klm/article/download $/ 4488 / 4105 \mathrm{ved}=2 \mathrm{a}$

h UKEwjLSf_n3NXoAhWKXSsKHZgBAIEQFjAMegQIBBABusg =AOvVaw2aW5-SMoLzF9WL8PFzLyQR

Hanifa, Putri Eka. 2016. Struktur Kalimat dalam Karangan Deskripsi Siswa Kelas VII SMP 13 Kota Tangerang. Jakarta. Universitas Islam Negeri Syarif Hidayatullah Jakarta.

Pangaribuan Tagor. 2008. Paragdigma Bahasa. Yogyakarta: Graham Ilmu. Samidi. 2011. Bahasa Indonesia Untuk SD/MI Kelas IV. Sidoarjo: Masmedia. Sanjaya Wina. 2006. Strategi Pembelajaran Berorientasi Standar Proses Pendidikan. Jakarta: Prenada media.

Santosa Puji. 2009. Materi dan Pembelajaran Bahasa Indonesia SD. Jakarta: Universitas Terbuka.

Sudjana Nana dan Rivai Ahmad. 2013. Media Pengajaran. Bandung: Sinar Baru Algensindo. Suprijono Agus. 2012. Cooperative learning Teori dan Aplikasi PAIKEM. Yogyakarta: Pustaka Belajar.

Susanto Ahmad. 2013. Teori Belajar dan Pembelajaran di Sekolah Dasar. Jakarta: Prenadamedia Group. Syah Darwan, Supardi, dan Muslihah Eneng. 2009. Strategi Belajar Mengajar. Jakarta: Diadit Media. Syah Muhibbin. 2013. 


\section{*Data Penulis}

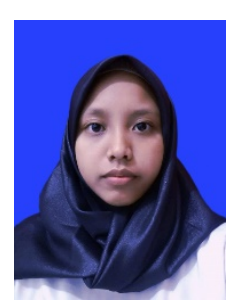

Hanna Kartika Sari (Hanna) 2005112453, lahir di Kotawaringin Barat, Kalimantan Tengah pada tanggal 25 November 2001. Ia merupakan Mahasiswa Prodi Pendidikan Bahasa dan Sastra Indonesia angkatan 2020 dengan jalur seleksi SBMPTN (Seleksi Bersama Masuk Perguruan Tinggi Negeri) dan sebagai alumni SMA N 1 Pangkalan Lesung (Pelalawan, Riau). Memiliki kegemaran dalam segala hal yang berbau seni (rupa, tari, vokal, dan lain-lain). Bergabung pada HIMA PBSI UNRI pada tahun 2021 sebagai anggota KOMINFO PBSI. Pada tahun 2020 memperoleh penghargaan sebagai peserta terbaik kelas tari dan meraih juara 2 dalam kompetensi seni Doodle pada MABA CUP 2021. Meraih dua kali pencapaian sebagai pemenang ke 2 lomba Kaligrafi Kontemporer tingkat FKIP dan Juara 1 pada tingkat Universitas. Meraih Juara pertama video kreatif pada efen Ulang Tahun PBSI yang ke 58 dan menghasilkan 1 karya seni.

Kontak :

HP/ WA : $082286768257 / 082287374101$

Email : hanna.kartika2453 